Gulawentah: Jurnal Studi Sosial

ISSN 2528-6293 (Print); ISSN 2528-6871 (Online)

Vol. 4, No. 1, Juli 2019, Hal 21-27

Tersedia Online: http://e-journal.unipma.ac.id/index.php/gulawentah

\title{
Peningkatan Kemampuan Guru Dalam Menyusun Tes Hasil Belajar IPS Melalui Supervisi Akademik Pada Guru Sd Negeri 4 Ngasinan Jetis Ponorogo
}

\author{
Endang Setiyawati \\ Magister Pendidikan Ilmu Pengetahuan Sosial, Universitas PGRI Madiun, Indonesia \\ Email: endangsetiyawati33@yahoo.co.id
}

\begin{abstract}
Abstrak
Penelitian ini termasuk jenis Penelitian Tindakan Sekolah (PTS) yang bertujuan untuk mengetahui peningkatkan kemampuan Guru SD Negeri 4 Ngasinan Kecamatan Jetis Kabupaten Ponorogo Semester Ganjil Tahun Pelajaran 2018/2019dalam menyusun tes hasil belajar IPS melalui supervisi akademik. Subyek penelitian ini adalah Guru SD Negeri 4 Ngasinan Jetis Ponorogo yang berjumlah 6 orang terdiri dari 1 guru laki-laki dan 5 guru perempuan. Penelitian inidimulai dari studi pendahuluan pada bulan Agustus sampai dengan bulan Desember 2018. Data dikumpulkan dengan teknik observasi, wawancara, dan dokumentasi.Teknik analisis data dalam penelitian Tindakan Sekolah ini berupa analisis statistik deskriptif dan analisiskualitatif model interaktif Miles dan Huberman.Penelitian ini dilaksanakan dalam dua siklus yang setiap siklus terdiri atas4 tahap yaitu:(1) perencanaan tindakan, (2) implementasi/ pelaksanaan tindakan, (3) observasi dan interpresentasi tindakan, (4) evaluasi dan refleksi. Hasil penelitian ini menunjukkan dari sisi proses Guru sangat mampu menyusun Tes Hasil Belajar IPS. Hal ini terlihat perbedaan skor penilaian pada prasiklus rata-rata skor nilainya sebesar 50, pada siklus I skor rata-rata nilainya menjadi 72, dan siklus II skor rata-ratanya meningkat nilainya menjadi 82.Sedangkan hasil Supervisi Akademis secara klasikalpadaprasiklus hanya 2 orang guru yang mampu dalam menyusun tes hasil belajar IPS (33,33\%), pada siklus I meningkat menjadi 4 orang guru yang mampu $(67,67 \%)$ dan pada siklus II meningkat secara keseluruhan menjadi 6 orang guru yang mampu menyusun tes hasil belajar IPS secara benar mencapai nilai 80 (100\%). Dapat disimpulkan bahwa kemampuan guru dalam menyusun tes hasil belajar IPS dapat ditingkatkan melalui supervisi akademik pada Guru SDNegeri 4 Ngasinan Kecamatan Jetis Kabupaten Ponorogo Semester Ganjil Tahun Pelajaran 2018/2019”.
\end{abstract}

Kata kunci: Srambang Park Ngawi; Ekonomi Masyarakat; Sumber Belajar IPS

Improvement of Teacher's Ability in Compiling Social Studies Learning Outcomes Tests Through Academic Supervision In 4 Ngasinan Jetis Ponorogo Primary School Teachers

\begin{abstract}
This study included the type of School Action Research (PTS) which aims to determine the improvement of the ability of 4 Ngasinan Elementary School Teachers in Jetis Subdistrict, Ponorogo Regency, Odd Semester 2018/2019 in compiling Social Studies learning outcomes tests through academic supervision. The subjects of this study were the 6 Ngasinan Jetis Ponorogo Public Elementary School Teachers consisting of 1 male teacher and 5 female teachers. This research starts from a preliminary study in August to December 2018. Data is collected by observation, interview, and documentation techniques. The data analysis technique in School Action research is in the form of descriptive statistical analysis and qualitative analysis of interactive models of Miles and Huberman. This research was conducted in two cycles, each cycle consisting of four stages, namely: (1) action planning, (2) implementation / implementation of actions, (3) observation and presentation of actions, (4) evaluation and reflection. The results of this study indicate that from the process side
\end{abstract}

DOI: 10.25273/gulawentah.v4i1.4989

Copyright (C) 2019 Universitas PGRI Madiun

All rights reserved. 
the teacher is very capable of compiling social studies learning tests. This can be seen the difference in the score on the pre-cycle average score of 50, in the first cycle the average score is 72, and the second cycle the average score increases to 82. While the results of the Academic Supervision classically on pre-cycle are only 2 people teachers who are able to compile social studies learning tests (33.33\%), in the first cycle increased to 4 capable teachers (67.67\%) and in the second cycle increased to 6 teachers who were able to properly compile social studies learning outcomes tests reach 80 (100\%). It can be concluded that the teacher's ability to prepare social studies learning tests can be improved through academic supervision of the 4 Ngasinan Elementary School Teachers, Jetis District, Ponorogo Regency, Odd Semester 2018/2019 Academic Year ".

Keywords: Srambang Park Ngawi; The Economic Society; Social Resources

\section{Pendahuluan}

Peraturan Pemerintah Nomor 19 Tahun 2005 tentang Standar Nasional menyatakan kompetensi pedagogik merupakan kemampuan dalam pengelolaan peserta didik meliputi: (a) pemahaman wawasan atau landasan kependidikan; (b) pemahaman terhadap pesertadidik; (c)pengembangan kurikulum/silabus;(d)perancanganpembelajaran; (e) pelaksanaan pembelajaran yang mendidik dan dialogis; (f) evaluasi hasil belajar; dan (g) pengembangan peserta didik untuk mengaktualisasikan berbagai potensi yang dimilikinya.Guru dituntut mampu menciptakan lingkungan belajar yang efektif dan menyenangkan serta lebih mampu mengelola kelasnya sehingga hasil belajar peserta didik optimal. Guru menguasai materi, mengolah program belajar mengajar, mengumpulkan informasi yang akurat tentang hasil belajar, minat dan kebutuhan pesertadidik melalui penilaian yang efektif, pertanyaan, observasi, pemberian tugas dan tes sehingga dapat mengetahui tingkat penguasaan peserta didik dan keefektifan proses pembelajaran dengan melaksanakan evaluasi hasil belajar danpengadministrasiannya.

Usaha memperbaiki mutu proses belajar mengajar dengan evaluasi hasil belajaruntuk mengukur kompetensi dicapai oleh peserta didik dari setiap proses pembelajaran atau setelah beberapa unit pelajaran untuk menentukan keputusan atau perlakuan terhadap peserta didik tersebut. Apakah perlu diadakan perbaikan atau penguatan, serta menentukan rencana pembelajaran berikutnya baik dari segi materi maupun rencana strateginya.Oleh karena itu, guru setidak-tidaknya mampu menyusun instrumen tes maupun non tes untuk membuat keputusan peserta didikapakah telah dicapai harapan penguasaannya secara optimal atau belum.

(Widoyoko, 2000) mengemukakan evaluasi hasil belajar merupakan penilaian dari proses pembelajaran untuk mengetahui kekuatan dan kelemahan berbagai komponen dalam suatu proses belajar mengajar. Kemampuan guru dalam melakukan evaluasi hasil belajar merupakan kompetensi guru yang sangat pentingsehingga kelas yang baik tidak cukup hanya didukung oleh perencanaan pembelajaran, kemampuan guru mengembangkan proses pembelajaran serta penguasaannya terhadap bahan ajar, dan juga tidak cukup dengan kemampuan guru dalam menguasai kelas, tanpa diimbangi dengan kemampuan melakukan evaluasi terhadap kompetensi peserta didik dalam konteks perencanaan berikutnya, atau kebijakan perlakuan terhadap peserta didik terkait dengan konsep belajar tuntas (Purwanto, 2004).

Menurut (Hamalik, 2001) evaluasi hasil belajar merupakan serangkaian kegiatan mengukur prestasi belajar peserta didik sebagai hasil dari suatu programintruksionalsebagai bukti evaluasi pengajaran, keberhasilan melaksanakan pembelajaran, dan mengetahui apakah suatu program pendidikan sudah dikuasai peserta didik atau belum. Dengan kata lain evaluasi hasil belajar merupakan penilaian untuk mengetahui kekuatan dan kelemahan dalam proses pembelajaran, sehingga dapat dijadikan dasar pengambilan keputusan apakah proses pembelajaran sudah baik atau 
masih perlu perbaikan (Sumarna \& Hatta, 2006). Pada studi pendahuluan yang dilakukan pada bulan Agustus 2018 ditemukan Guru SD Negeri 4 Ngasinan Kecamatan Jetis Kabupaten Ponorogo masih belum optimal melaksanakan evaluasi hasil belajar dengan baik sebagaimana yang ditegaskan dalam Peraturan Menteri Pendidikan dan Kebudayaan nomor 23 tahun 2016.

Hal ini didukung hasil Dokumentasi Penilaian Kinerja Guru Tahun 2017 pada kompetensi pedagogik pada item kemampuan gurumembuat tes, melakukan pengukuran, dan menilai dari kompetensi peserta didikuntuk memperbaiki kualitas proses belajar mengajar pada aspek evaluasi pembelajaran ini masih belum optimalyakni $80 \%$ (4 orang) guru kurang mampu dalam menyusun tes hasil belajar sesuai dengan rubrik penyusunan tes hasil belajar Kurikulum 2013.Guru memberikan penilaian belum sesuai harapan. Soal tes buatan guru kadang-kadang kurang obyektif, kurang valid, dan kurang sistematis yang berpengaruh pada prestasi peserta didik. Guru banyak fokus pada pemberian pelajaran saja, namun, saat guru membuat soal ujian atau tesdisusun seadanya tanpa memenuhi penyusunan soal yang baik dan benar serta pengolahan evaluasi pembelajaran secara formatif.

Salah satu tindakan yang harus dilakukan kepala sekolah adalah membimbing dan membina guru dalam kegiatan supervisi akademik untukmeningkatkan kemampuan professional guru bukan hanya mengelola proses pembelajaran di kelas namun juga untuk menilaian kinerja guru dalam penilaian peserta didik. Hal ini sesuai dengan Permendiknas Nomor 13 Tahun 2007tentang Standard KepalaSekolahmenetapkan bahwa ada lima dimensi kompetensi kepala sekolah/madrasah meliputi kepribadian, managerial, kewirausahaan, supervisi dan social sehingga Kepala Sekolah bertanggung jawab dalam pelaksanaan pendidikan di sekolah sebagai edukator, manager, administrator, supervisor, leader, inovator dan motivator (EMASLIM) sehingga kepala sekolah harus dapat meningkatkan kinerja dan kemampuan guru.

Ada beberapa penelitian sebelumnya tentang supervisi akademik sebagai solusi alternatif untuk mengatasi masalah kemampuan guru dalam tes hasil belajar. (Marimin, 2017) menunjukkan bahwa penerapan supervisi akademik dapat meningkatkan kinerja guru dalam menyusun tes hasil belajar. Mennulikan bahwa melalui workshop dapat meningkatkan kemampuan guru kelas IV, V, dan VI di KKG Gugus 02 Kecamatan Sumbermalang dalam menyusun tes hasil belajar akhir semester (Osnal, O., Suhartoni, S., \& Wahyudi, 2016). Menurut (Rokhmat, 2017) supervisi akademik dapat memberikan peningkatan kompetensi guru dalam penyusunan desain penilaian.

\section{Metode Penelitian}

Jenis penelitian ini yaitu Penelitian Tindakan Sekolah (School Action Research) atau PTS. PTS merupakan penelitian tindakan untuk memecahkan masalah proses pembelajaran di tingkat persekolahan. Dalam konteks inipenelitian tindakan sekolah (PTS) sebagai upaya Kepala Sekolah untuk meningkatan kinerja guru melalui supervisi dengan model siklus. Dalam setiap siklus terdiri atas4 tahap yaitu:(1) perencanaan tindakan, (2) implementasi/ pelaksanaan tindakan, (3) observasi dan interpresentasi tindakan, (4) evaluasi dan refleksi. Prosedur pemecahan masalah sepertibagankan di bawah ini: 


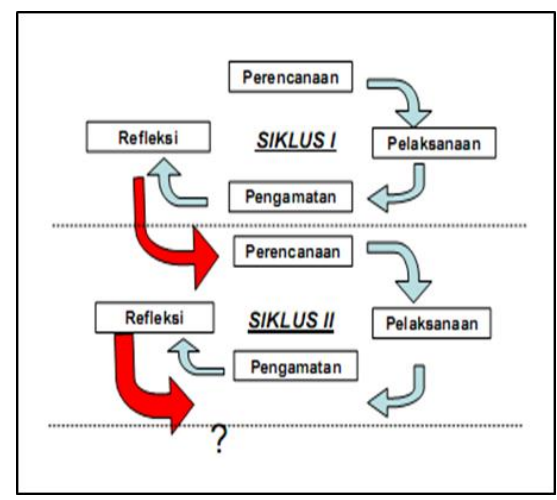

Gambar 1. Alur Penelitian

Guna memperjelas prosedur kerja yang dilakukan dalam penelitian ini maka dipandang perlu untuk disampaikan indikator kinerja sebagai berikut.

Tabel 1. Indikator Kinerja Penelitian

\begin{tabular}{lrlrl}
\hline \multicolumn{1}{c}{ Rumusan Masalah } & \multicolumn{2}{c}{ Tujuan } & \multicolumn{2}{c}{ Indikator Kinerja } \\
\hline Apakah supervisi akademik dapat & Untuk mengetahui supervisi & Kemampuan guru dalam \\
meningkatkan kemampuan & guru & akademik & dapat & menyusun tes hasil belajar IPS \\
dalam menyusun tes hasil belajar IPS & meningkatankemampuan guru & dapat ditingkatkan dengan \\
pada guru di SD Negeri 4 Ngasinan & dalam menyusun tes hasil & Supervisi Akademik mencapai \\
Jetis Ponorogo Semester Ganjil & belajar IPS pada guru di SD & $80 \%$ dari guru yang ada di SD \\
Tahun Pelajaran 2018/2019?" & Negeri 4 Ngasinan Jetis & Negeri 4 Ngasinan Jetis Ponorogo \\
& Ponorogo Semester Ganjil & Semester Ganjil Tahun Pelajaran \\
& Tahun Pelajaran 2018/2019. & 2018/2019.
\end{tabular}

Subyek penelitian ini adalah guru kelas I sampai dengan kelas VI di SD Negeri 4 Ngasinan Kecamatan Jetis Kabupaten Ponorogo yang berjumlah 6 guru yang terdiri 1 guru laki-laki dan 5 guru perempuan. Dengan pengumpulan data melaluiObservasi, wawancara, dan dokumentasi.

\section{Hasil dan Pembahasan}

Deskripsi aktivitas dalam penelitian tindakan Sekolah ini adalahPeningkatan Kemampuan Guru Dalam Menyusun Tes Hasil Belajar IPS melalui Supervisi Akademik Pada Guru SD Negeri 4 Ngasinan Jetis Ponorogo Tahun Pelajaran 2018/2019'.Sebelum siklus 1 dimulai, peneliti mengadakan observasi prasiklus sebagai pembanding peningkatan kualitas ke siklus 1.Kegiatan prasiklus dengan dokumentasi hasil administrasi perangkat penilaian guru dalam melakukan analisis ulangan harian IPS dengan menggunakan rubrik penilaian.

Hasil rekapitulasi penilaian kemampuan guru menyusun tes hasil belajar IPS pada prasiklus diperoleh skor penilaian guru sebesar 50 dan dari 6 (enam) guru hanya ada 2 guru yang mampu menyusun tes hasil belajar IPS berarti hanya 33\% guru yang memenuhi kemampuan menyusun tes hasil belajar IPS. 
Deskripsi dalam paparan data hasil penelitian ini, peneliti akan menjabarkan kegiatan per siklus yang dilaksanakan selama penelitian berlangsung. Penjabarannya adalah (a) Siklus 1 dan (b) siklus 2 .

Pada bagian refleksi ini dikemukakan beberapa hal tentang proses dan pelaksanaan Peningkatan Kemampuan Guru Dalam Menyusun Tes Hasil Belajar IPS melalui Supervisi Akademik Pada Guru SD Negeri 4 Ngasinan Jetis Ponorogo Tahun Pelajaran 2018/2019dengan melakukan tindakan evaluasi meliputi evaluasi mutu, jumlah, dan waktu dari setiap macam tindakan, pertemuan dengan guru sertaEvaluasi tindakan pada siklus I diperoleh data bahwa pelaksanaan tindakan siklus I sesuai jadwal yang disusun dengan memfokuskan hasil penyusunan tes hasil belajar IPS tertuang pada analisis hasil ulangan harian.

Hasil pada siklus I ada peningkatan skor yang diperoleh guru-guru kelas dalam menyusun tes hasil belajar IPS, dibuktikan dengan 4 guru dinyatakan mampu dalam menyusun tes hasil belajar dan rata-rata perolehan skor penilaian 72 atau $67 \%$ guru yang sudah memenuhi kategori mampu. Pelaksanaan siklus ke dua lebih berhasil daripada siklus pertama. Pada bagian refleksi ini tentang proses dan pelaksanaan pada siklus II, ada perubahan signifikan berupa peningkatan kemampuan guru dalam menyusun tes hasil belajar IPS. Secara individual dan klasikal semua guru sudah masuk dalam katagori mampu dalam menyusun tes hasil belajar IPS, dengan rata-rata skor hasil penilaian 82.

Tolok ukur keberhasilan penelitian tindakan Sekolah ini yang dilakukan dalam II siklus terlihat dari dua sisi, yaitu dari sisi proses dan dari sisi hasil. Dari sisi proses, ada peningkatan kemampuan guru menyusun tes hasil belajar IPS, baik secara klasikal maupun individu. Secara individu seorang guru dinyatakan mampu menyusun tes hasil belajar jika mendapatkan skor $51-75$ dan dinyatakan sangat mampu jika mendapatkan skor $76-100$. Hal ini dapat dilihat pada tabel 2 dan 3.

Tabel 2. Rata-rata skor guru secara klasikal

\begin{tabular}{cccccc}
\hline \multicolumn{2}{c}{ Prasiklus } & \multicolumn{2}{c}{ SIKLUS I } & \multicolumn{2}{c}{ SIKLUS II } \\
\hline Skor & Kategori & Skor & Kategori & Skor & Kategori \\
\hline 50 & Kurang & 72 & Baik & 82 & Amat Baik
\end{tabular}

Dari sisi hasil secara klasikalseorang guru dinyatakan mampu dalam menyusun tes hasil belajar jika mampu menyusun tes hasil belajar secara benar mencapai nilai 80 .

Tabel 3. Capaian Nilai Guru dalam Penelitian

\begin{tabular}{|c|c|c|c|c|c|c|c|c|}
\hline \multirow[t]{3}{*}{ No } & \multirow[t]{3}{*}{ Nilai } & \multirow[t]{3}{*}{ Kriteria } & \multicolumn{2}{|c|}{ Prasiklus } & \multicolumn{2}{|c|}{ SIKLUS I } & \multicolumn{2}{|c|}{ SIKLUS II } \\
\hline & & & Jumlah & $\%$ & Jumlah & $\%$ & Jumlah & $\%$ \\
\hline & & & Guru & & Guru & & Guru & \\
\hline 1 & $50-59$ & D & - & - & - & - & - & - \\
\hline 2 & $60-69$ & $\mathrm{C}$ & 2 & 33,33 & - & - & - & - \\
\hline 3 & 70-79 & B & 4 & 66,67 & 4 & 66,67 & - & - \\
\hline 4 & $\geq 80$ & A & - & - & 2 & 33,33 & 6 & 100 \\
\hline
\end{tabular}

Kemampuan guru dalam melakukan evaluasi hasil belajar merupakan kompetensi guru yang sangat penting sehingga kelas yang baik tidak cukup hanya didukung oleh perencanaan pembelajaran, kemampuan guru mengembangkan proses pembelajaran serta penguasaannya 
terhadap bahan ajar, kemampuan guru dalam menguasai kelas, kemampuan melakukan evaluasi terhadap kompetensi peserta didik dalam konteks perencanaan berikutnya, atau kebijakan perlakuan terhadap peserta didik terkait konsep belajar tuntas.

Dengan penyusunan hasil tes belajar IPS, Guru telah mengukur prestasi belajar peserta didik dalam matapelajaran IPS sebagai hasil dari suatu program intruksional sebagai bukti evaluasi pengajaran, keberhasilan melaksanakan pembelajaran, dan mengetahui apakah materi IPS sudah dikuasai peserta didik atau belum, serta mengetahui kekuatan dan kelemahan dalam proses pembelajaran, sehingga Guru dapat pengambilan keputusan apakah proses pembelajaran sudah baik atau masih perlu perbaikan. Penilaian pembelajaran sudah dilakukan Guru mulai dari pengumpulan dan pengolahan informasi dalam aspek sikap, aspek pengetahuan, dan aspek keterampilan yang dilakukan secara terencana dan sistematis untuk memantau proses, kemajuan belajar, dan perbaikan hasil belajar melalui penugasan untuk mengukur pencapaian hasil belajar peserta didik.

Supervisi akademik yang dilakukan kepala sekolah dapat meningkatkan kompetensi pedagogik menjadi guru profesional bukan hanya mengajar, mendidik, melatih, dan menilai hasil pembelajaran peserta didik. Menurut (Rosilawati, 2014) supervisi akademik hendaknya dilanjutkan dengan penagihan komitmen dari guru dan bimbingan dari kepala sekolah dan pengawas sekolah. Sebuah komunitas belajar diantara sesame guru disekolah perlu dibangun guna meningkatkan kualitas pembelajaran dan hasil belajar siswa di lapangan (Samsudin, 2014). Supervisi akademik dapat dijadikan sebuah pembiasaan kepada guru dalam rangka menghadapi penilai kinerja guru, harapannya jika sudah terbiasa dengan supervisi akademik maka pelaksanaan PKG dapat berjalan lancar (Damayanti, 2016). Supervisi akdemik hendaknya mampu menjalankan fungsi sumatif penilaian dengan mengukur dan menilai tingkat pencapaian kompetensi peserta didik, mendeskripsikan capaian hasil pembelajaran peserta didik, dan fungsi formatif untuk mendiagnostik kesulitan belajar, dan memberi petunjuk bagi pendidik dalam meningkatkan mutu pembelajaran, mengetahui kekuatan dan kelemahan dalam proses pembelajaran sehingga dijadikan dasar pengambilan keputusan dan perbaikan proses pembelajaran yang dilakukan (Hardono, Haryono, \& Yusuf, 2017; Ramadhan, 2017).

\section{Simpulan}

Supervisi akademik dapat meningkatkan kemampuan guru dalam menyusun tes hasil belajar IPS. Hal ini terlihat pada prasiklus diperoleh skor penilaian guru telah mampu menyusun tes hasil belajar sebesar 50,pada siklus I skor rata-rata nilainya 72, dan siklus II skor rata-ratanya nilainya 82 . Hal ini berarti Guru sangat mampu menyusun Tes Hasil Belajar IPS. Dari segi Hasil, Supervisi Akademis secara klasikalguru mampu dalam menyusun tes hasil belajar IPS secara benar mencapai nilai 80 . Pada pra siklus hanya 2 orang guru yang mampu (33,33\%), pada siklus I ada4 orang guru yang mampu $(67,67 \%)$ dan pada siklus II meningkat menjadi 6 orng guru yang mampu menyusun tes hasil belajar (100\%). Dengan demikian terjadi peningkatan yang sangat signifikan dari dari siklus I ke siklus II.

\section{Daftar Pustaka}

Damayanti, W. (2016). Peningkatan Mutu Kinerja Guru Melalui Supervisi Akademik Di Smk Negeri 1 Salatiga Menghadapi Pkg 2016. Jurnal Pendidikan Ilmu Sosial, 26(1), 80-86.

Hamalik, O. (2001). Kurikulum dan Pembelajaran. Jakarta: Bumi Aksara.

Hardono, H., Haryono, H., \& Yusuf, A. (2017). Kepemimpinan Kepala Sekolah, Supervisi Akademik, dan Motivasi Kerja dalam Meningkatkan Kinerja Guru. Educational Management, 
$6(1), 26-33$.

Marimin, M. (2017). Upaya Meningkatkan Kemampuan Guru dalam Menyusun Tes Hasil Belajar Akhir Semester I melalui Supervisi Akademik Pada Kelas V Dabin II Pattimura Kecamatan Jatiyoso Tahun Pelajaran. Jurnal Ilmiah Mitra Swara Ganesha, 4(1), 37-57.

Osnal, O., Suhartoni, S., \& Wahyudi, I. (2016). Meningkatkan Kemampuan Guru dalam Menyusun Tes Hasil Belajar Akhir Semester melalui Workshop di KKG Gugus 02 Kecamatan Sumbermalang Tahun 2014/2015. Pancaran Pendidikan, 5(1), 67-82.

Purwanto. (2004). Evaluasi Hasil Belajar. Yogyakarta: Pustaka Pelajar.

Ramadhan, A. (2017). Pengaruh Pelaksanaan Supervisi Akademik Pengawas Sekolah Dan Supervisi Kepala Sekolah Terhadap Kinerja Guru SMK Negeri Di Kabupaten Majene. Journal of Educational Science and Technology (EST), 3(2), 136. https://doi.org/10.26858/est.v3i2.3579

Rokhmat, N. (2017). Peningkatan Kompetensi Guru Dalam Menyusun Desain Penilaian Melalui Supervisi Akademik Bagi Guru Mata Pelajaran IPS. Entrance Jurnal Pendidikan, 1(1), 246262.

Rosilawati, T. (2014). Supervisi Akademik dalam Upaya Peningkatan Motivasi Guru Menyusun Perangkat Persiapan Pembelajaran. Jurnal Penelitian Tindakan Sekolah Dan Kepengawasan, $1(2), 57-62$.

Samsudin, A. (2014). Supervisi Akademik Pembelajaran IPA Melalui ICT Based Lesson. Mimbar Sekolah Dasar, 1(1), 77-82.

Sumarna, S., \& Hatta, M. (2006). Penilaian Portofolio Implementasi Kurikulum 2004. Bandung: PT Remaja Rosda Karya.

Widoyoko, S. E. P. (2000). Evaluasi Program Pembelajaran (Instructional Program Education). 